\title{
SURVEY OF SOME RICE INSECT PESTS AND THEIR PREDATORS IN THREE DISTRICTS OF SRI LANKA
}

\author{
G.F. RAJENDRAM AND FRANCESCA R. DEVARAJAH \\ Department of Zoology, University of Jaffna, Jaffna, Sri Lanka.
}

\author{
(Date of receipt : 25th August 1986) \\ (Date of acceptance : $12 \mathrm{th}$ March 1990)
}

\begin{abstract}
Sampling for planthoppers, leafhoppers and other minor pests was carried out in rice fields, kept free of insecticides, in the districts of Batticaloa, Kilinochi and Jaffna, during Maha 1981-82 and Yala 1982, using the sweep net technique. The brown planthopper Nilaparvata lugens (Stal) was recorded in Batticaloa and Jaffna districts and Sogatella furcifera Horvath in Kilinochi. The leafhoppers Nephotettix virescens (Distant) and Nephotettix nigropictus (Stal) were recorded from all three districts. The minor pests collected included Leptocorisa oratorius (Fabricius), Scotinophora lurida Burmeister, Nezara viridula Linnaeus, Tanymecus sp., Aulacophora sp., Acrididae, Tettigoniidae and Gryllidae. Insect predators recorded were Cyrtorbinus lividipennis Reuter, two Coccinellids Micraspsis discolor and Harmonia octomaculata, a Staphylinid Paederus fuscipes Curtis and an Anthocorid. Other general predators observed belong to the Odonata - Lestes sp., Pseudagrion sp., Ortbetrum sp. and Anax sp.
\end{abstract}

\section{Introduction}

The increase in the destructiveness of the planthopper and leafhopper pests of the rice crop during the last decade has followed the introduction of high yielding, nitrogen-responsive rice varieties. ${ }^{16}$ The brown. planthopper Nilaparvata lugens (Stal) is one of the most destructive pests of the rice crop in Southeast Asia, causing damage through feeding as well as by transmitting the virus diseases - "grassy stunt"8 and "ragged stunt".6 Among the leafhoppers, Nephotettix virescens (Distant), Nephotettix nigropictus (Stal) and Recilia dorsalis (Motschulsky) also transmit the virus diseases "rice tungro", "rice dwarf" and "yellow dwarf".

Population sutdies on the planthopper and leathopper complexes of the rice crop and their natural cnemies in Sri Lanka have been carried out in Kandy and surrounding districts by Santa ef al. ${ }^{14}$ and in Amparai district by Otake et al. ${ }^{9}$ The present paper records the results of a survey of planthopper and leafhopper pests of the rice crop, as well as other minor pests, and their insect predators, in rice fields located in the Batticaloa, Kilinochi and Jaffna districts. The survey "was carried out during two rice growing seasons - Maha season of 1981-82 and Yala season of 1982. Of the insect predators, the prospect of using Cyrtorhinus lividipennis Reuter for the control of $N$. lugens is discussed in detail.

\section{Materials and Methods}

Three paddy fields were selected for sampling in Karadianaru, Kilinochi and 
Jaffna. Karadianaru is approximately 18 miles west of Batticaloa and Kilinochi 42 miles south of Jaffna. Two plots of ca. $700 \mathrm{sq} \mathrm{m}$ each were selected in each location. The fields were thoroughly ploughed and puddled and $V_{1}$ fertilizer mixture with NPK at 4:30:12 ratio broadcast at the rate of $126 \mathrm{~kg}$ per hectare. The paddy seeds of rice variety BG 90-2 were soaked for 2 days to break the dormancy and then sown on a wet field at the rate of $166 \mathrm{~kg}$ per hectare. Fourteen days after sowing, urea was applied at the rate of $162 \mathrm{~kg}$ per hectare. The plots were kept free of insecticides during the entire period of growth.

Sampling was carried out using a $25 \mathrm{~cm}$ diameter insect net with a $90 \mathrm{~cm}$ handle. A single $180^{\circ}$ angle stroke of the net was considered as one sweep. The sweeps were made just above the level of the rice plants. Eighty sweeps were made at each plot covering two thirds of the area. The insects were collected in separate glass vials after every 10 sweeps. The mean \pm SD for 10 sweeps was calculated and presented.

Sampling commenced from the second week of sowing and was continued until the 12 th week, i.e just before harvest. (Sampling was continued till the 10th week in Karadianaru in Maha 1981-82). Sampling was repeated at fortnightly intervals at all three locations. The identification of insects was carried out by the senior author and confirmed by reference to specimens maintained at the Entomological Museum of the International Rice Research Institute in Los Banos, Philippines.

\section{Results}

\subsection{Karadianaru}

\subsubsection{Maha 1981-82}

The pest insects collected are recorded in Figure 1A. $N$. virescens and $N$. nigropictus numbered $0.35 \pm 0.02$ per 10 sweeps in the 6 th week, increasing to $0.48 \pm 0.03$ in the 8 th week. They were not present in the 2 nd to 4 th week after planting. Leptocorisa oratorius (Fabricius) was recorded in the 6 th and 8th week, numbering $0.5 \pm 0.02$ and $3.5 \pm 0.2$ respectively. Scotinophora lurida Burmeister was the same $0.13 \pm 0.01$ in the 6 th and 8 th week after planting. Nezara viridula Linnaeus numbered $0.1 \pm 0.01$ and $0.65 \pm$ 0.02 in the 8 th and 10 th week respectively.

The beneficial insects collected are indicated in Figure 1B. The Coccinellids Micraspsis discolor and Harmonia octomaculata were present in the 8 th and 10th week, numbering together $0.98 \pm 0.03$ and $0.38 \pm 0.01$ per 10 sweeps respectively. The general predators Lestes sp. (Lestidae) and Pseudagrion sp. (Ceonagrionidae) were present throughout the sampling period. 


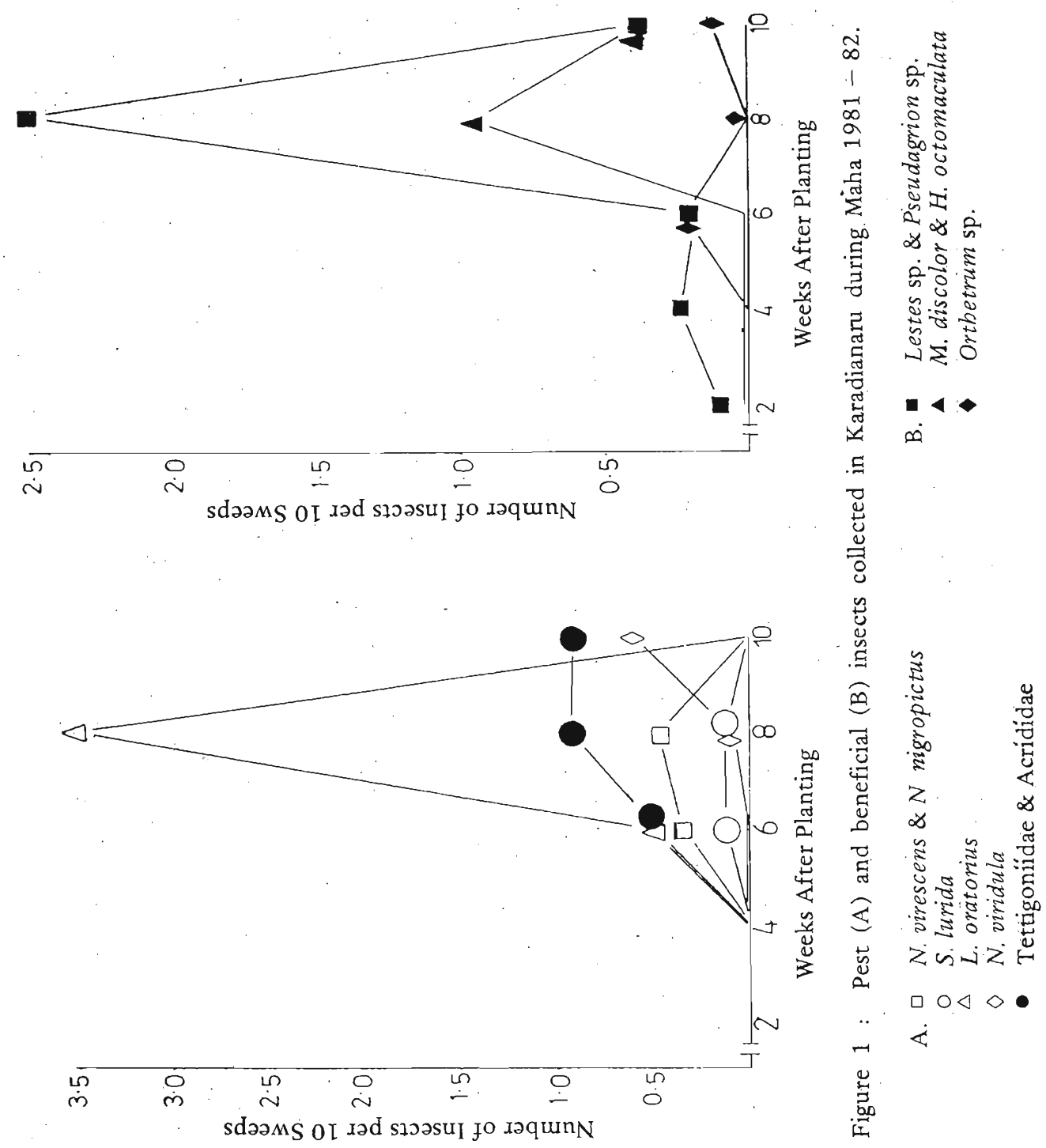




\subsubsection{Yala 1982}

Among the pest insects collected (Figure 2A), $N$. lugens was present in the 6 th and 8 th week after planting, numbering $0.42 \pm 0.02$ and $0.33 \neq 0.02$ per 10 sweeps respectively. $N$. virescens and $N$. nigropictus were present in the 8th, 10th and 12th week, numbering $0.1 \pm 0.02,0.4 \pm 0.02$ and $0.25 \pm 0.01$ respectively. The rice root weevil Tanymecus sp. was present at a density of $0.08 \pm 0.02$ and $0.02 \pm 0.01$ in the 6 th and 8 th week respectively. (This is a first record in Sri Lanka.) Tettigoniidae and Gryllidae were also recorded.

The following beneficial insects were collected (Figure 2B). The Coccinellids $M$. discolor and $H$, octomaculata were present in the 4th, 8th, 10 th and 12th week, "numbering together $0.08 \pm 0.02,0.6 \pm 0.03,1.5 \pm 0.3$ and $0.83 \pm 0.02$ per 10 sweeps respectively. The Staphylinid Paederus fuscipes Curtis was present in the 4 th, 8 th, 10 th and 12 th week after planting, numbering $0.08 \pm 0.02,0.1 \pm 0.02,0.1 \pm 0.02$ and $0.17 \pm 0.01$ respectively. Anthocoridae were present in the fields from the 4th to 12th week, reaching a peak of $0.75 \pm 0.03$ in the 6 th week. Lestes sp. and Orthetrum sp. were also recorded.

\subsection{Kilinochi}

\subsubsection{Maha 1981-82}

The following pest insects were collected (Figure 3A). L. oratorius was observed in the 12 th week, at $0.5 \pm 0.02$ per 10 sweeps. Acrididae were also recorded.

The predators collected were $M$. discolor and $H$. octomaculata in the 12th week and Lestes sp., Pseudagrion sp. and Orthetrum sp. in the 4th and 6 th week (Figure 3B).

\subsubsection{Yala 1982}

The following pest insects were collected (Figure 4A). S. furcifera numbered $6.15 \pm 0.3$ and $1.25 \pm 0.2$ per 10 sweeps in the 6 th and 8 th week respectively. $N$. virescens and $N$. nigropictus were present at $0.75 \pm 0.03$ in the 4 th and 8 th week. Aulacophora sp. numbered $0.25 \pm 0.01$ in the 6 th week. Acrididae and Tettigoniidae were also present.

The following predators were collected (Figure 4B). M. discolor and H. octomaculata were present at a total density of $1.5 \pm 0.3,0.25 \pm 0.01$ and $0.5 \pm 0.02$ per 10 sweeps in the 4 th, 6 th and 10 th week respectively. Anthocoridae were present at $1.2 \pm 0.3$ per 10 sweeps in the 6 th week. Lestes sp., Orthetrum sp. and Anax sp. (Aeschnidae) were also present. 


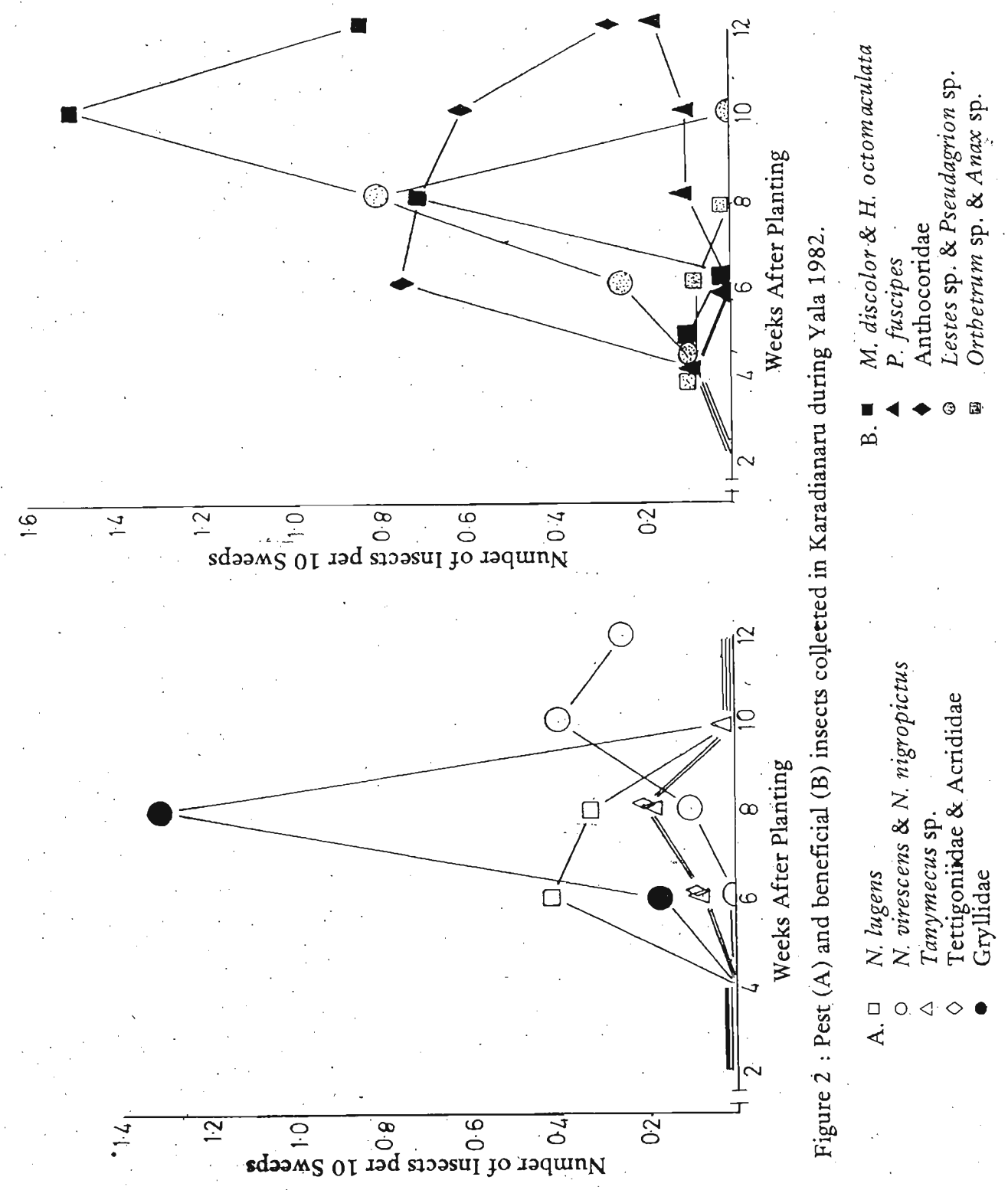




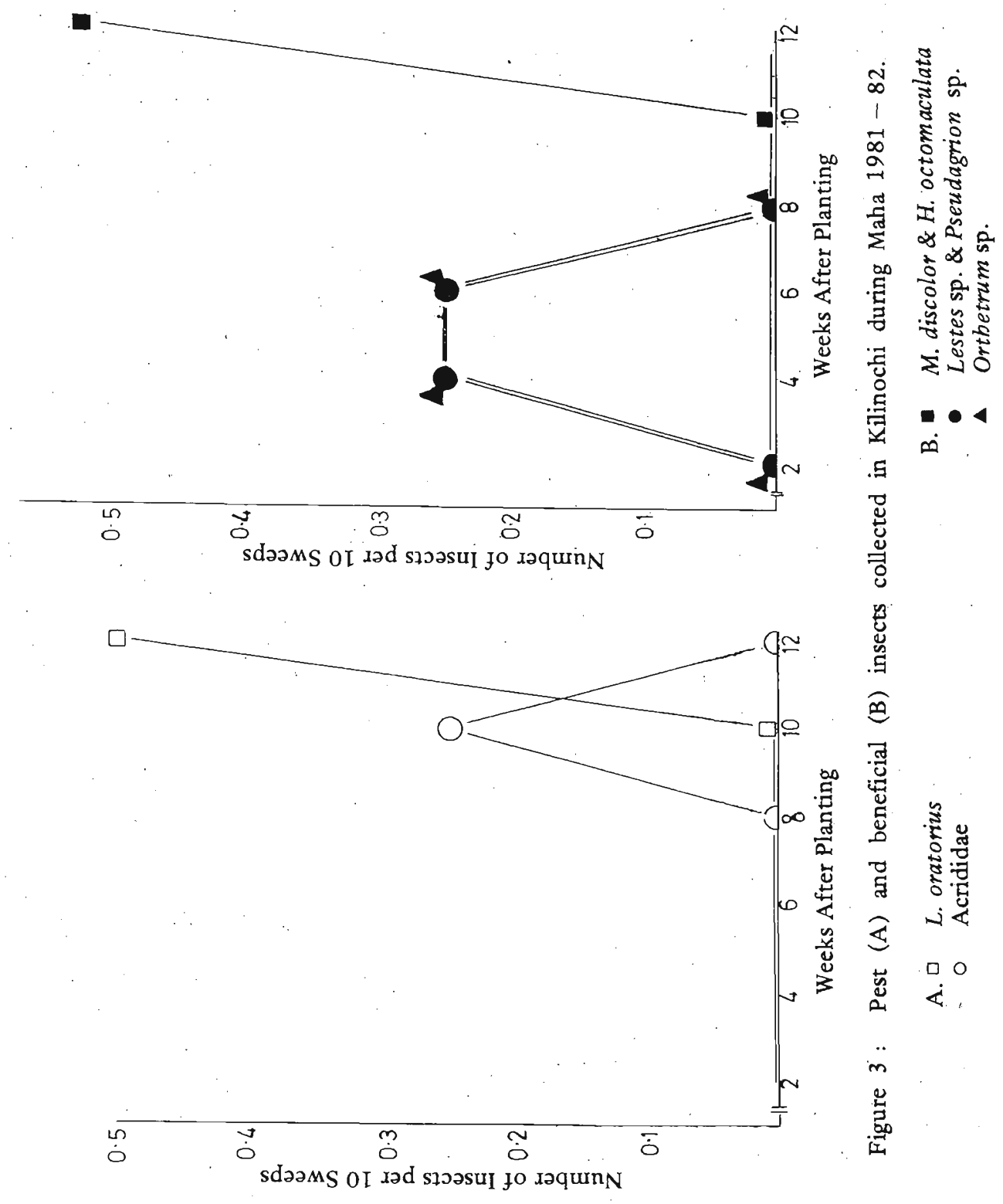




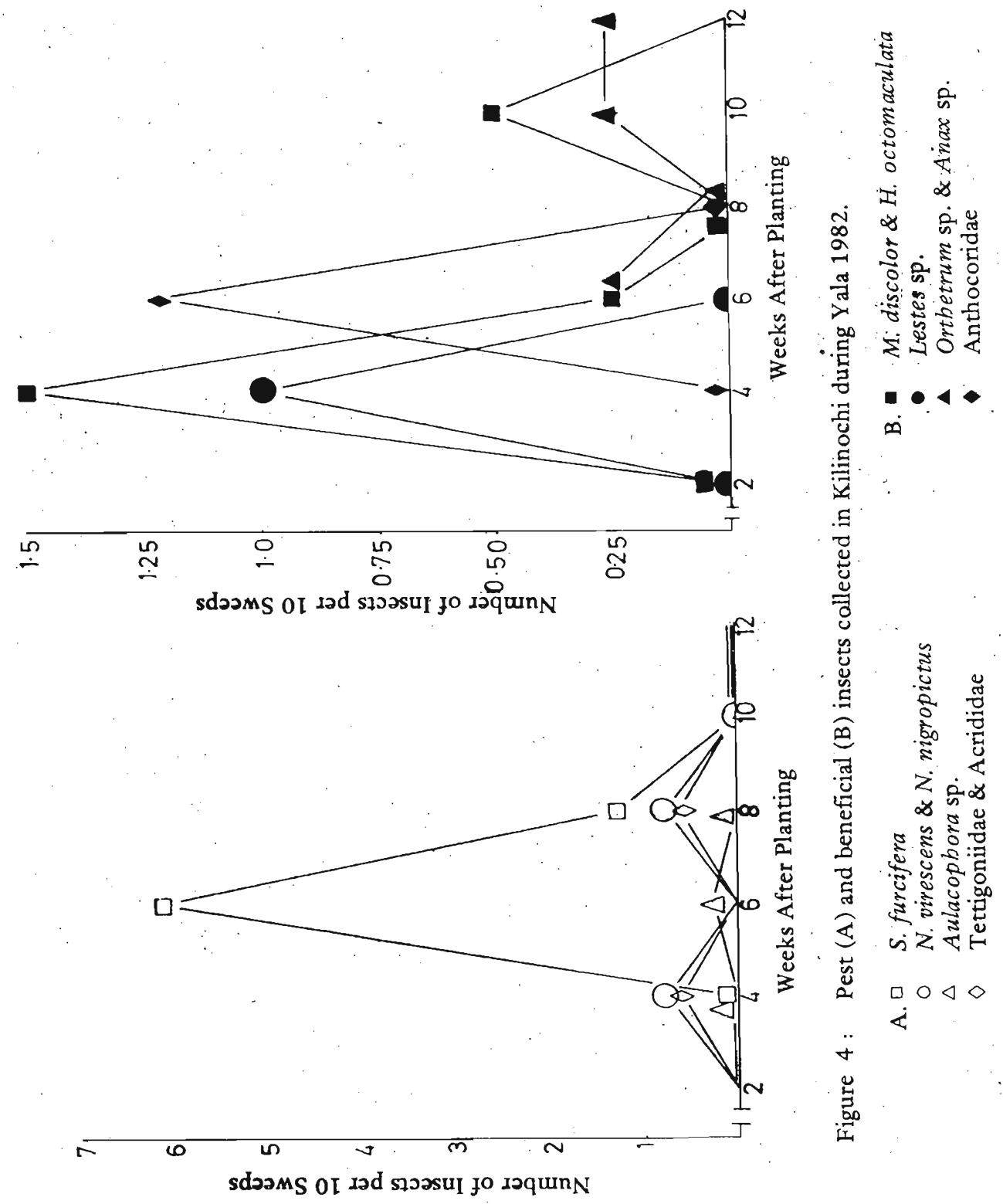




\subsection{Jaffna}

\subsubsection{Maha 1981-82}

The following pest insects were collected (Figure 5A). N. lugens was recorded in the 8th week at $0.25 \pm 0.01$ per 10 sweeps. $N$. virescens and $N$. nigropictus were present only in the 10 th week, numbering $1.66 \pm 0.3$. $L$. oratorius numbered $0.66 \pm 0.02,1.0 \pm 0.22,5.33 \pm 0.6$ and $1.0 \pm 0.03$ in the 4 th, 6 th, 8 th and 10 th week respectively. The rice root weevil Tanymecus sp. was present in the 6 th week at a low density of $0.33 \pm 0.02$. Aulacophora sp. numbered $0.66 \pm 0.03,0.33 \pm 0.02$ and $0.33 \pm 0.02$ in the 4 th, 8 th and 10th week respectively. Members of the families Tettigoniidae, Acrididae and Gryllidae were also recorded.

The beneficial insects collected were the following (Figure 5B). C. lividipennis was collected in the 6 th week numbering $0.33 \pm 0.02$ per 10 sweeps. $\bar{M}$. discolor was present in the 6 th and 10 th week, numbering $2.0 \pm 0.03$ and $1.0 \pm 0.02$ respectively. Lestes sp. and Pseudagrion sp. were also recorded.

\subsubsection{Yala. 1982}

The following pest insects were present (Figure 6A). L. oratorius was present in the 10th and 12th week at the same density of $1.33 \pm 0.07$ per 10 sweeps. The rice root weevil Tanymecus sp. was present at the density of $0.33 \pm 0.02$ and $0.33 \pm 0.03$ in the 6 th and 10 th week. Acrididae were also collected.

Two beneficial insects were collected (Figure 6B). C. lividipennis was present in the 6th and 10th week after planting, at the same density of $0.33 \pm 0.02$ per 10 sweeps. H. octomaculata was present in the 6 th, 8 th, 10 th and 12 th week at densities of $0.33 \pm 0.02,0.33 \pm 0.01,0.66 \pm 0.03$ and $0.33 \pm 0.01$ respectively. 


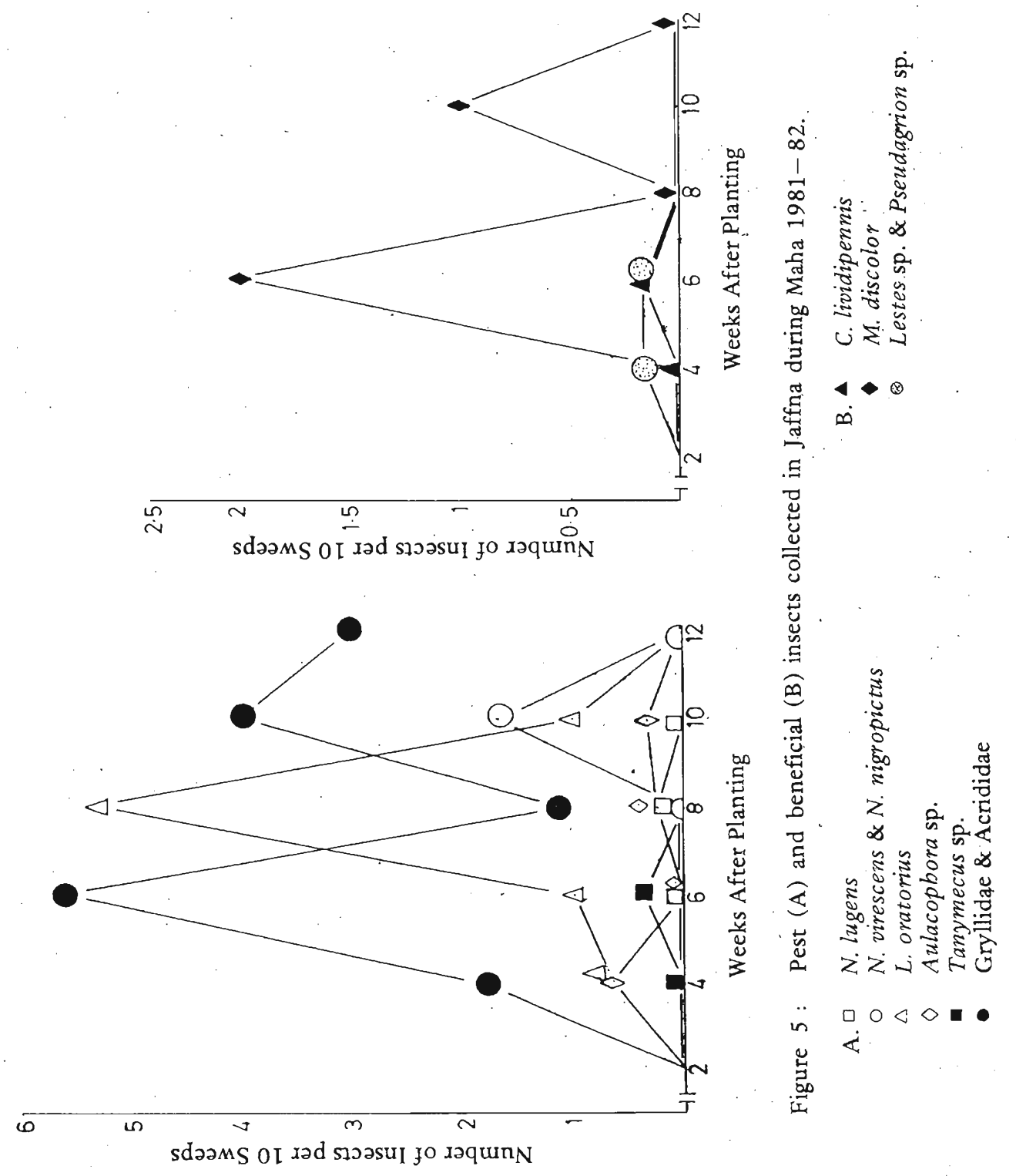



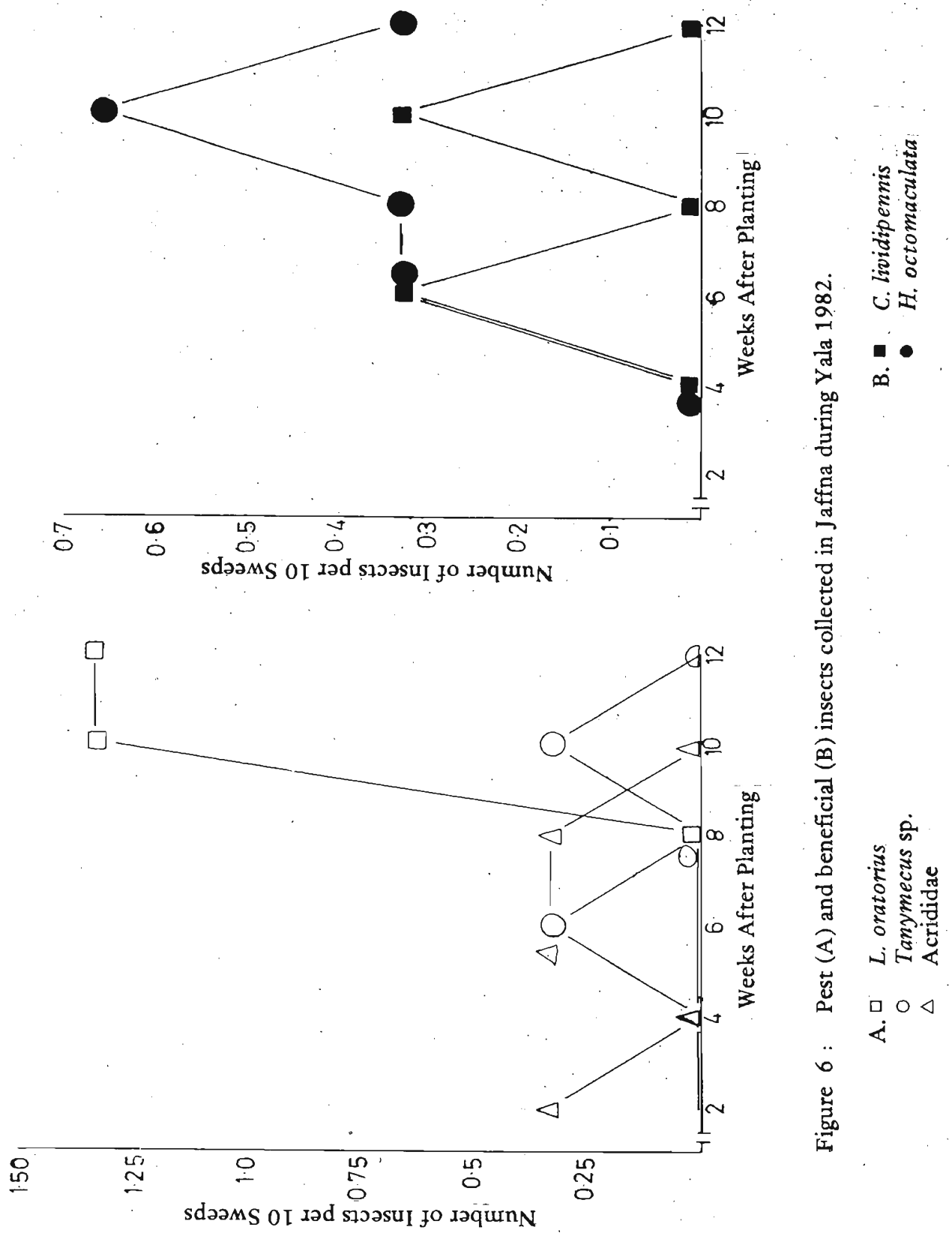


\section{Discussion}

In Karadianaru, $N$. lugens was recorded only during. Yala 1982; it was not recorded during Maha 1981-82. But C. lividipennis was not present during the entire period of sampling. Neither $N$. lugens nor $C$. lividipennis was present during either season at Kilinochi. In Jaffna, both $N$. lugens and C. lividipennis were present during Maha 1981-82 while only C. lividipennis was present in Yala'1982. Hence we can conclude that the distribution patterns of both $N$. lugens and C. lividipennis tend to be localized. This was confirmed by personal observation of other paddy fields in the districts. During Maha 1981-82, though N. lugens was not present at Karadianaru, a severe infestation was observed in Kalmunai, only a distance of 20 miles (as the planthopper flies) from Karadianaru. And although C. lividipennis was not observed at Kilinochi during both seasons, it was present at Paranthan, only 2 miles distant from the Kilinochi rice fields under study. It was noted however that paddy was planted in rows at Paranthan. Previous research in the distribution of C. lividipennis in India seems to indicate that planting in rows, with space between tillers, encourages the presence of C. lividipennis in rice fields (S. Nagarkatti : personal communication).

In Jaffna, during Maha 1981-82, $N$. lugens, $N$. virescens, $N$. nigropictus and $C$. lividipennis were present. In the following season, Yala 1982, only $C$. lividipennis was present. It could not be determined if the absence of the planthopper-leafhopper complex during Yala 1982 was directly due to the predatory activity of C. lividipennis during Maha 1981-82. N. virescens and $N$. nigropictus were present during both seasons at Karadianaru and during Yala 1982 at Kilinochi. It was also not possible to determine the precise role, if any; of $C$. lividipennis and $M$. discolor in the subsequent reduction of the high density of $L$. oratorius, Gryllidae and Acrididae noted during the 4 th to 8 th week, during Maha 1981, in Jaffna.

Among the parameters to be considered in the explanation of the varying densities of $N$. lugens and C. lividipennis, the rice variety is not a factor, since the same variety BG 90-2 was used in all three fields. This variety is susceptible to attack and population build up of the planthopper and leafhopper complex.

The role of the abiotic factors could not account for the difference in population densities of $N$. lugens and C. lividipennis in the fields sampled. The rainfall during the months of sampling during Maha 1981-82, October to December, in Karadianaru, Kilinochi and Jaffna are 21.96 in, 24.0 in and 20.33 in respectively. The corresponding figures for Yala 1982, April to June, are $5.06 \mathrm{in}, 4.88$ in and 2.09 in. The temperature range in the locations are respectively $24.3-30.6^{\circ} \mathrm{C}, 25.0-30.5^{\circ} \mathrm{C}$ and $25.2-30.1^{\circ} \mathrm{C}$ in Karadianaru, Kilinochi and Jaffna respectively. The differences do not appear to be significant enough to explain the differences in the composition of the populations of $N$. ligens and C. lividipennis in the locations sampled. 
Fernando ${ }^{2}$ and Otake et al. ${ }^{9}$ recorded $N$. lugens as the predominant planthopper species in Amparai district. Fernando ${ }^{2}$ also recorded this as the predominant planthopper species in Batticaloa district. Otake et al: ${ }^{9}$ also observed the leafhopper species of $N$. virescens and $N$. nigropictus. They also reported a Cyrtorhinus sp., 2 coccinellids, the assasin bug (Reduviid) and Casnoidea interstialis, a carabid. S. furcifera, noted in Kilinochi in the present study, was indicated as the predominant planthopper species in Kandy and surrounding districts by Santa et al. ${ }^{14}$ These workers also reported that $N$. lugens was present only in small numbers and $C$. lividipennis made up $25 \%$ of the insect population while $N$. virescens and $N$. nigropictus together accounted for $37 \%$ of the insect population.

The present survey was undertaken to consider the prospects of biological control of $N$. lugens by $C$. lividipennis. In the light of the present findings, the following may be mentioned. Studies have already been carried out in Sri Lanka on the biology of $N$ lugens ${ }^{11}$ and of $C$. lividipennis. ${ }^{12}$ Laboratory studies are also available on the predatory effectiveness of $C$. lividipennis on $N$. lugens. ${ }^{13}$ Though field studies on the predatory effectiveness of C. lividipennis on $N$. lugens are not available from Sri Lanka, such studies are available from other countries. Hinckley ${ }^{3}$ mentions that $C$. lividipennis was an important source of $N$. lugens mortality in Fiji. Stapley ${ }^{18}$ credited Cyrtrohinus sp. with a cultural practical role in controlling $N$. lugens in Solomon Islands. These workers stress the importance of the role of grass as a reservoir for populations of C. lividipennis. Stapley ${ }^{17}$ suggests that Eleusine indica and Eleusine coracanna may be the favoured grass that maintain Cyrtorhinus sp. in Solomon Islands. Stapley ${ }^{18}$ also claims that Cyrtorhinus sp. invades rice where there is an abundance of grass, especially Digitaria in the vicinity. Since these grass species - E. indica, E. coracanna and Digitaria adscendens are widespread in both dry and wet.lowlands of Sri Lanka according to Senaratne,,$^{15}$ these grasses may be hidden reservoirs of C. lividipennis in lowland paddy fields. Planting of such grasses on the borders of paddy fields may augment the reservoir populations of $C$. lividipennis and thus help in the biological control of $N$. lugens. Confirmation however could be obtained only by direct sampling of these grasses.

Though these grasses are not found in the hills, the transplanting of paddy in rows with space between tillers may explain the frequent occurence of $C$. lividipennis in paddy fields in Kandy as reported by Santa et al. ${ }^{14}$

The present study shows that the absence of synchrony among the generation patterns of $N$. lugens and $C$. lividipennis could severely limit the effectiveness of this predator in suppressing outbreaks of $N$. lugens populations. The presence of the predators recorded in this survey may compensate for such lack of synchrony. $M$. discolor and $H$. octomaculata were observed in all three locations during both seasons. P. fuscipes was present in Karadianaru during Yala 1982 and in Jaffna during Maha 1981-82 and Yala 1982. Anthocorids were noted in Karadianaru and Kilinochi during Yala 1982. 
Hence the biological control of $N$. lugens by $C$. lividipennis in Sri Lanka appears to be feasible. Further studies are under way to determine the actual role of these grasses as reservoirs of $C$. lividipennis in Sri Lanka.

\section{Acknowledgement}

Grateful thanks are due to the following : Professor V. K. Ganesalingam, Head, Department of Zoology, University of Jaffna, for facilities ; Dr. E. A. Heinrichs, Entomologist, International Rice Research Institute, Los Banos, Philippines, for access to the Museum facilities to carry out identifications ; Mr. K. Puvaneswaran, Geography Department, University of Jaffna, for weather data ; Miss. Derina Fernando for typing the Manuscript ; the Natural Resources, Energy and Science Authority of Sri Lanka for part financial assistance under grant no. RGB/80/53.

\section{References}

1. DYCK, V.A. \& ORLIDO, G.C. (1977) Control of the brown planthopper (Nilaparvata lugens) by natural enemies and timely application of narrow spectrum insecticides. The Rice Brown Planthopper, 58 - 70. Food and Fertiliser Technology Centre for the Asian and Pacific Region, Taiwan.

2. FERNANDO, H.E. (1975) The brown plenthopper problem in Sri Lanka. Rice Entomology Newsletter $2: 34-36$.

3. HINCKLEY, A.D. (1963) Ecology and control of rice planthoppers in Fiji. Bull. Ent. Res. 54(3) : $467-481$.

4. International Rice Research Institute (1972) Annual Report for 1971. Los Banos, Philippines.

5. International Rice Research Institute (1973) Annual Report for 1972. Los Banos, Philippines.

6. International Rice Research Institute (1978) Annual Report for 1977. Los Banos, Philippines.

7. KALODE, M.B. (1983) Leafhopper and planthopper pests of rice in India. 1st International Workshop on Leafhoppers and Planthoppers of Economic Importance, 225 - 245. Commonwealth Institute of Entomology, London.

8. LING, K.C. (1967) Transmission of viruses in south-east Asia. The Virus Diseases of the Rice Plant, 139 - 153. John Hopkins, Baltimore, U.S.A.

9. OTAKE, A., SOMASUNDARAM, P.H. \& ABEYKOON, M.B. (1976) Studies on populations of Sogatella furcifera Horvath and Nilaparvata lugens Stal (Hemiptera : Delphacidae) and their parasites in Sri Lanka. Appl. Entomol. Zool. 11(4) : $284-294$.

10. RAJENDRAM, G.F. (1982) The brown planthopper problem. Presidential Address, Section D. Proc. Sri Lanka Assoc. Advmt. Sci. 38(1), $49-54$.

11. RAJENDRAM, G.F. \& DANIEL, D.J.E. (1986) Observations on the biology of Nilaparvata lugens (Homoptera : Delphacidae). Vingnanam - J. Sci. 1 : 8-13.

12. RAJENDRAM, G.F. \& DEVARAJAH, F.R. (1986) Observations on the biology of Cyrtorbinus lividipennis (Hemiptera : Miridae). Vingnanam -J:Sci. $1: 14-18$. 
13. RAJENDR.AM, G.F. \& DEVARAJAH, F.R. (1987) Studies on the predatory effectiveness of Cyrtorbinus lividipennis (Hemiptera : Miridae) on Nilaparvata lugens (Homopte ra : Delphacidae). Vingnanam - J. Sci. 2 : $35-43$.

14. SANTA, H., SOMASUNDARAM, P.H. \& ABEYKOON, M.B. (1973) Studies on the planthopper and leafbopper complex of paddy in Sri Lanka. Central Agricultural Research Institute Report, Sri Lanka.

15. SENARATNA, S.D.J.E. (1956) The Grasses of Cejlon. Colombo.

16. SMITH, R.F. (1972) The impact of the green revolution on plant protection in tropical and subtropical areas. Bull. Ent. Soc. Amer. $18: 7-14$.

17. STAPLEY, J.H. (1975) The problem of the brown planthopper (Nilaparvata lugens) on rice in the Solomon Islands. Rice Entmol. Newsl. $2: 37-38$.

18. STAPLEY, J.H. (1976) The brown planthopper and Cyrtorbinus sp predators in the Solomon Islands. Rice Entomol. Newsl. 4 : $15-16$. 